\title{
Effect of growth regulators on the branching ability of maiden apple trees of the 'Šampion' and 'Jonica' cultivars
}

\author{
Magdalena Kaplan \\ University of Life Sciences in Lublin \\ Department of Seed Production and Nurseries \\ Leszczyńskiego 58, 20-068 Lublin, Poland \\ e-mail: magdalena.kaplan@up.lublin.pl
}

\begin{abstract}
In 2000-2003, studies were conducted in the Felin Experimental Station at the University of Agriculture in Lublin to evaluate the impact of BA $+\mathrm{GA}_{3} 2.2 \%$ (Arbolin $036 \mathrm{SL}$ ) and $\mathrm{BA}+\mathrm{GA}_{4+7} 2.2 \%$ and $3.75 \%$ (Promalin 3.6 SL) in the form of lanolin paste on the increase of the number of lateral shoots in maiden apple trees of the 'Šampion' and 'Jonica' cultivars. The growth regulators were found to have a beneficial effect on the branching ability of the maidens of the studied cultivars. 'Jonica' showed weaker apical dominance than 'Šampion'. Young 'Jonica' trees had more lateral shoots of greater length than the 'Šampion' maidens.
\end{abstract}

Key words: BA+GA 3 (Arbolin 036 SL), BA+GA ${ }_{4+7}$ (Promalin 3.6 SL), lanolin paste, preparations stimulating branching, rootstock

\section{INTRODUCTION}

The quality of the nursery stock has proven to be a key determinant of the precocity of the bearing period and the size of apple tree crops (Bielicki et al. 2003). Nursery tree quality depends on the growth strength of the rootstock applied, the natural branching habits of the cultivar, soil and climate conditions and finally, the efficiency of various nursery practices stimulating branching (Poniedziałek and Porębski 1992, 1995, Tromp 1992, Bielicki et al. 1994, Wertheim and Estabrooks 1994, Hrotko et al. 1996, Jacyna 1996, Czarnecki 1989, Jaumień and Dziuban 1998, Gąstoł et al. 1999, Kapłan 2006, Kapłan and Baryła 2006 a, b).

The objective of the present research was to evaluate the impact of $\mathrm{BA}+\mathrm{GA}_{3}$ (Arbolin $036 \mathrm{SL}$ ) and $\mathrm{BA}+\mathrm{GA}_{4+7}$ (Promalin 3.6 SL) preparations applied in the form of lanolin paste on the branching potential and increase of sylleptic shoot number of maiden apple trees of the 'Šampion' and 'Jonica' cultivars.

\section{MATERIAL AND METHODS}

The studies were conducted in the years 2000-2003 in the Felin Experimental Station at the University of Agriculture in Lublin. The research material consisted of 'Šampion' and 'Jonica' maiden apple trees budded on M.9 RN 29 and M.26 rootstocks.

The rootstocks were planted in the spring of 2000, 2001 and 2002 at nursery spacing of $90 \times$ $30 \mathrm{~cm}$; in the summer they were pruned and finally on $15^{\text {th }}$ July, the 'Šampion' and 'Jonica' trees were chip-budded at $15 \mathrm{~cm}$ above ground level. In their second nursery year in early July (5 July), when the maidens were approximately $75 \mathrm{~cm}$ high, the bioregulators were applied in the form of a lanolin paste. The paste was prepared a day prior to treatment at the following concentrations: $2.2 \%$ $\mathrm{BA}+\mathrm{GA}_{3}\left(2.2 \mathrm{ml} \mathrm{BA}+\mathrm{GA}_{3}\right.$ per $100 \mathrm{~g}$ lanolin $)$ 
and $2.2 \%$ and $3.75 \% \mathrm{BA}+\mathrm{GA}_{4+7}(2.20 \mathrm{ml}$ and $3.75 \mathrm{ml} \mathrm{BA}+\mathrm{GA}_{4+7}$ per $100 \mathrm{~g}$ lanolin). The lanolin paste was applied with a small brush thoroughly covering six lateral buds and the bark around them. This type of bioregulator carrier facilitated the very precise spread of the paste over the lateral buds and prevented the preparations from drying too quickly.

The study was carried out in three independent series: 2000/2001, 2001/2002, and 2002/2003. In each series, the experiment was set up according to a randomized block design (16 combinations in $5 \times 10$ plants). A replication was made by a plot with 10 plants.

In the years 2001, 2002, and 2003 in the second year of maiden tree growth in the nursery, measurements of the number and length of all the lateral shoots as well as of those developed after the bioregulator treatment were performed.

The research data was analyzed statistically using the analysis of variance, while the T-Tukey test was employed to assess the significance of differences at a significance level of $5 \%$.

\section{RESULTS}

The mean number of shoots produced after bioregulator application ranged between 1.3 and 4.2 (Tab. 1). The highest number of shoots from the bioregulator-treated buds appeared in the combinations with $\mathrm{BA}+\mathrm{GA}_{4+7} 3.75 \%$. There was no significant influence of preparation type on the analyzed traits; however, the apple maidens treated with $\mathrm{BA}+\mathrm{GA}_{4+7} 2.2 \%$ developed slightly fewer shoots than those treated with the $\mathrm{BA}+\mathrm{GA}_{3} 2.2 \%$ treatment, except for 'Šampion' trees grafted on
M.26. It was demonstrated that the preparation dose, cultivar type and rootstock applied affected the branching potential of the maiden trees under study. The trees exposed to the more concentrated BA + $\mathrm{GA}_{4+7}$ preparation formed more shoots compared to those where the lower concentration of $\mathrm{BA}+$ $\mathrm{GA}_{4+7}$ was applied. The differences appeared to be significant for the 'Šampion' maidens developed on M.9. In the majority of the combinations used, the 'Šampion' apple maidens produced fewer lateral shoots than those of the 'Jonica' cultivar. The maiden trees on M.9 formed fewer laterals than on M.26, except for the trees treated with $\mathrm{BA}+\mathrm{GA}_{4+7}$ $3.75 \%$.

The number of total lateral shoots per tree was within the range of 3.1-9.8 (Tab. 1). The bioregulator treatments were found to have a beneficial impact on the studied trait. The control maiden trees formed fewer lateral shoots than those with growth regulators applied. The best feathered maiden trees proved to be those treated with the BA $+\mathrm{GA}_{4+7} 3.75 \%$ mixture, and in the case of 'Jonica' trees on M.9, the differences were significant. No significant influence of preparation type or dose as well as cultivar or rootstock on the studied trait was shown. It was noted that at the higher, and not lower, $\mathrm{BA}+\mathrm{GA}_{4+7}$ concentration, the maiden trees responded with a higher number of shoots produced. Significantly, the 'Jonica' trees subjected to the $\mathrm{BA}+\mathrm{GA}_{4+7} 3.75 \%$ treatment appeared to be significantly better branched than the 'Šampion' control maiden trees as well as those with the BA+ $\mathrm{GA}_{3}$ and $\mathrm{BA}+\mathrm{GA}_{4+7} 2.2 \%$ application.

The present research revealed that the highest sum of lateral shoot length of the bioregulator-

Table 1. Effect of growth regulators on lateral shoot number of maiden apple trees of the 'Šampion' and 'Jonica' cultivars

\begin{tabular}{|c|c|c|c|c|}
\hline \multirow[b]{2}{*}{ Combination } & \multicolumn{4}{|c|}{ Number of lateral shoots per tree produced after growth regulator application } \\
\hline & ‘Šampion’ M.9 & 'Jonica' M.9 & ‘Šampion’ M.26 & 'Jonica' M.26 \\
\hline Control & - & - & - & - \\
\hline $\mathrm{BA}+\mathrm{GA}_{3} 2.2 \%$ & $1.8 \mathrm{bc}^{*}$ & $2.2 \mathrm{abc}$ & $2.1 \mathrm{abc}$ & $2.6 \mathrm{abc}$ \\
\hline $\mathrm{BA}+\mathrm{GA}_{4+7} 2.2 \%$ & $1.3 \mathrm{c}$ & $2.1 \mathrm{abc}$ & $3.0 \mathrm{abc}$ & $2.5 \mathrm{abc}$ \\
\hline $\mathrm{BA}+\mathrm{GA}_{4+7} 3.75 \%$ & $3.5 \mathrm{ab}$ & $4.2 \mathrm{a}$ & $3.4 \mathrm{abc}$ & $3.8 \mathrm{ab}$ \\
\hline \multirow[t]{2}{*}{$\mathrm{LSD}_{0.05}$} & \multicolumn{4}{|c|}{2.1} \\
\hline & \multicolumn{4}{|c|}{ Total number of lateral shoots per tree } \\
\hline Control & $3.3 \mathrm{c}$ & $4.9 \mathrm{c}$ & $3.1 \mathrm{c}$ & $5.3 \mathrm{bc}$ \\
\hline $\mathrm{BA}+\mathrm{GA}_{3} 2.2 \%$ & $4.7 \mathrm{c}$ & $6.1 \mathrm{abc}$ & $4.7 \mathrm{c}$ & $7.4 \mathrm{abc}$ \\
\hline $\mathrm{BA}+\mathrm{GA}_{4+7} 2.2 \%$ & $4.6 \mathrm{c}$ & $6.9 \mathrm{abc}$ & $4.5 \mathrm{c}$ & $6.9 \mathrm{abc}$ \\
\hline $\mathrm{BA}+\mathrm{GA}_{4+7} 3.75 \%$ & $6.9 \mathrm{abc}$ & $9.8 \mathrm{a}$ & $5.3 \mathrm{bc}$ & $9.3 \mathrm{ab}$ \\
\hline $\mathrm{LSD}_{0.05}$ & \multicolumn{4}{|c|}{4.3} \\
\hline
\end{tabular}

*Means followed by the same letter are not significantly different at $\mathrm{p}=0.05$ 
Table 2. Effect of growth regulators on the total shoot length of apple maidens of the 'Šampion' and 'Jonica' cultivars

\begin{tabular}{|c|c|c|c|c|}
\hline \multirow[b]{2}{*}{ Combination } & \multicolumn{4}{|c|}{ Total length of shoots developed after growth regulators applicaton $\left(\mathrm{cm}\right.$ tree $\left.^{-1}\right)$} \\
\hline & ‘Šampion’ M.9 & 'Jonica' M.9 & ‘Šampion’ M.26 & 'Jonica' M.26 \\
\hline Control & - & - & - & - \\
\hline $\mathrm{BA}+\mathrm{GA}_{3} 2.2 \%$ & $20.7 \mathrm{~cd}^{*}$ & $47.2 \mathrm{~cd}$ & $22.3 \mathrm{~cd}$ & $53.4 \mathrm{bc}$ \\
\hline $\mathrm{BA}+\mathrm{GA}_{4+7} 2.2 \%$ & $5.9 \mathrm{~d}$ & $59.0 \mathrm{bc}$ & $21.8 \mathrm{~cd}$ & $29.2 \mathrm{~cd}$ \\
\hline $\mathrm{BA}+\mathrm{GA}_{4+7} 3.75 \%$ & $52.0 \mathrm{bcd}$ & $108.9 \mathrm{a}$ & $30.8 \mathrm{~cd}$ & $94.2 \mathrm{ab}$ \\
\hline \multirow[t]{2}{*}{$\mathrm{LSD}_{0.05}$} & \multicolumn{4}{|c|}{46.4} \\
\hline & \multicolumn{4}{|c|}{ Total length of shoots $\left(\mathrm{cm}\right.$ tree $\left.^{-1}\right)$} \\
\hline Control & $63.6 \mathrm{~d}$ & 166.4 abcd & $60.2 \mathrm{~d}$ & $196.5 \mathrm{abc}$ \\
\hline $\mathrm{BA}+\mathrm{GA}_{3} 2.2 \%$ & $64.1 \mathrm{~d}$ & $169.5 \mathrm{abcd}$ & $73.1 \mathrm{~cd}$ & $198.1 \mathrm{abc}$ \\
\hline $\mathrm{BA}+\mathrm{GA}_{4+7} 2.2 \%$ & $42.5 \mathrm{~d}$ & $196.9 \mathrm{abc}$ & $40.9 \mathrm{~d}$ & $135.4 \mathrm{bcd}$ \\
\hline $\mathrm{BA}+\mathrm{GA}_{4+7} 3.75 \%$ & $111.5 \mathrm{~cd}$ & $283.2 \mathrm{a}$ & $72.9 \mathrm{~cd}$ & $252.9 \mathrm{ab}$ \\
\hline $\mathrm{LSD}_{0.05}$ & \multicolumn{4}{|c|}{130.0} \\
\hline
\end{tabular}

*Explanations: see Table 1

applied trees was recorded for the maiden trees treated with the $\mathrm{BA}+\mathrm{GA}_{4+7} 3.75 \%$ treatment; the differences were significant for 'Jonica' on M.9 rootstock (Tab. 2). However, no significant effect was reported for preparation type or rootstock on the studied trait. As for the 'Jonica' maiden trees, it was shown that the trait was dependent on the preparation dose; at the higher $\mathrm{BA}+\mathrm{GA}_{4+7}$ concentration, a significantly greater total shoot length was noted as compared to the lower one. The total length of shoots formed from the bioregulatortreated buds depended on the cultivar. The maiden trees of the 'Jonica' cultivar were characterized by a higher total shoot length compared to the 'Šampion' variety, and the differences proved to be significant for the maidens on M.9 and treated with $\mathrm{BA}+\mathrm{GA}_{4+7}$ as well as those on M.26 and subjected to the treatment with the higher concentrated BA+ $\mathrm{GA}_{4+7}$ preparation.

The total length of shoots ranged from 40.9 up to $283.2 \mathrm{~cm}$. No significant influence of the preparation type, its concentration or rootstock type on the investigated trait was demonstrated. It was observed that of the combinations tested, the apple maidens treated with $\mathrm{BA}+\mathrm{GA}_{4+7} 3.75 \%$ had a greater lateral shoot length. A significant effect of the cultivar type was shown in the case of the trees budded on M.9 and those subjected to BA $+\mathrm{GA}_{4+7}$ treatment at both doses as well as those on M.26 treated with $\mathrm{BA}+\mathrm{GA}_{4+7} 3.75 \%$.

The length of a lateral shoot on the trees where growth regulators were applied was found to be between 2.7 and $25.3 \mathrm{~cm}$, and was significantly dependent on the cultivar (Tab. 3). The 'Jonica' apple maiden trees demonstrated significantly

Table 3. Effect of growth regulators on the lateral shoot length of apple maidens of the 'Šampion' and 'Jonica' cultivars

\begin{tabular}{|c|c|c|c|c|}
\hline \multirow[b]{2}{*}{ Combination } & \multicolumn{4}{|c|}{ Average length of a lateral shoot developed after growth regulators treatment $\left(\mathrm{cm} \mathrm{shoot}^{-1}\right)$} \\
\hline & ‘Šampion’ M.9 & 'Jonica' M.9 & ‘Šampion’ M.26 & 'Jonica' M.26 \\
\hline Control & - & - & - & - \\
\hline $\mathrm{BA}+\mathrm{GA}_{3} 2.2 \%$ & $8.5 \mathrm{cde}^{*}$ & $25.3 \mathrm{a}$ & $6.1 \mathrm{de}$ & $17.5 \mathrm{abc}$ \\
\hline $\mathrm{BA}+\mathrm{GA}_{4+7} 2.2 \%$ & $2.7 \mathrm{e}$ & $22.6 \mathrm{ab}$ & $6.3 \mathrm{de}$ & $13.4 \mathrm{bcd}$ \\
\hline $\mathrm{BA}+\mathrm{GA}_{4+7} 3.75 \%$ & 11.2 cde & $24.4 \mathrm{a}$ & 7.5 cde & $22.9 \mathrm{ab}$ \\
\hline \multirow[t]{2}{*}{$\mathrm{LSD}_{0.05}$} & \multicolumn{4}{|c|}{10.6} \\
\hline & \multicolumn{4}{|c|}{ Average length of a lateral shoot $\left(\mathrm{cm} \mathrm{shoot}^{-1}\right)$} \\
\hline Control & 13.7 bcde & $25.7 \mathrm{ab}$ & 14.9 a-e & $26.7 \mathrm{a}$ \\
\hline $\mathrm{BA}+\mathrm{GA}_{3} 2.2 \%$ & $11.9 \mathrm{de}$ & $26.4 \mathrm{a}$ & $10.6 \mathrm{e}$ & 23.9 abcd \\
\hline $\mathrm{BA}+\mathrm{GA}_{4+7} 2.2 \%$ & $7.4 \mathrm{e}$ & $26.1 \mathrm{a}$ & $7.1 \mathrm{e}$ & $17.7 \mathrm{a}-\mathrm{e}$ \\
\hline $\mathrm{BA}+\mathrm{GA}_{4+7} 3.75 \%$ & $12.6 \mathrm{cde}$ & $25.9 \mathrm{a}$ & $10.1 \mathrm{e}$ & $24.1 \mathrm{abc}$ \\
\hline $\mathrm{LSD}_{0.05}$ & \multicolumn{4}{|c|}{12.0} \\
\hline
\end{tabular}

*Explanations: see Table 1 
longer lateral shoots as compared to the 'Šampion' trees. The differences were only insignificant in the case of the trees grafted on M.26 and treated with $\mathrm{BA}+\mathrm{GA}_{4+7}$ at the $2.2 \%$ concentration. No significant impact of the preparation type and dose as well as rootstock type on the trait studied was recorded.

The applied growth regulators did not have a significant influence on the average length of the lateral shoots (Tab. 3). There were no significant differences between the control and the treated trees. However, the 'Šampion' and 'Jonica' maidens on M.26 treated with growth regulators were demonstrated to have shorter lateral shoots than the control. The trees where BA $+\mathrm{GA}_{3}$ was applied had slightly longer shoots as compared to those treated with $\mathrm{BA}+\mathrm{GA}_{4+7} 2.2 \%$. A significant impact of the cultivar on the studied trait was confirmed in the combinations with growth regulator application. Significantly longer shoots were reported for the 'Jonica' than the 'Šampion' trees. However, no significant effect of the preparation dose and rootstock type was observed on the trait studied.

\section{DISCUSSION}

The present research has proven that the growth regulators applied had a beneficial influence on the branching degree of the 'Šampion' and 'Jonica' apple maiden cultivars.

In all of the cultivars under study, the apple control maiden trees formed lower lateral shoot counts than those with growth regulators applied. A survey of the literature revealed the fact that numerous papers (Czarnecki 1989, Poniedziałek and Porębski 1992, 1995, Basak et al. 1993, Jacyna 1996, Jaumień and Dziuban 1998, Gąstoł et al. 1999) emphasize the favorable effect of growth regulators on the degree of branching of young apple trees. The authors do agree that bioregulators affected a number of lateral shoots positively.

On average, the most shoots appeared in the combinations where $\mathrm{BA}+\mathrm{GA}_{4+7} 3.75 \%$ was applied and the least in the combinations with $\mathrm{BA}+\mathrm{GA}_{4+7}$ $2.2 \%$. The great variability observed in the efficiency of branch-stimulating preparations was reported by Poniedziałek and Porębski (1995), Jaumień and Dziuban (1998), and Bielicki et al. (1994). In the study performed by Jaumień and Dziuban (1998), the percentage of branched maidens treated with the $\mathrm{BA}+\mathrm{GA}_{3}$ at $250 \mathrm{mg} \mathrm{dm}^{-1}$ concentration with adjuvant was $70-100 \%$, similarly at higher conc. 85 $100 \%$, whereas for the unsprayed apple maidens, 0-65\%. Poniedziałek and Porębski (1995) found a pronounced and strong effect of $\mathrm{BA}+\mathrm{GA}_{3}$ on shoot number and a slightly lower, yet still significant impact of sprayed BA. The research by Bielicki et al. (1994) showed that Paturyl in the form of lanolin paste resulted in the highest percentage of branched young trees.

The research data confirmed that 'Jonica' was characterized by a weaker apical dominance as compared to 'Šampion' (Rejman et al. 2002, Kapłan and Baryła 2006 a). It was noted that the control young 'Jonica' trees formed more lateral shoots than the 'Šampion' trees.

Jaumień and Dziuban (1998) demonstrated impact of the rootstocks on branching ability. Dwarfing rootstocks tended to inhibit the development of laterals (Bielicki et al. 1994), which was in agreement with Czarnecki's findings (1989) that showed that M.26 rootstock induced the formation of a greater number of laterals than M.9. The research data did not show a significant influence of the rootstock on the branching ability of the apple maidens after investigation.

In the current study, it was found that the maiden apple trees with growth regulators applied had a greater number of laterals than the control ones. In most of the observed apple maidens that were exposed to higher concentrated a BA $+\mathrm{GA}_{4+7}$ compound, a higher sum of laterals was obtained than in the other combinations. This is consistent with Jaumień and Dziuban's (1998) results, revealing that the sum of the lateral shoot length, like their number, was significantly higher in the apple maidens sprayed with growth regulators as compared to the unsprayed ones. As for the 'Gloster' maiden trees, an Arbolin 036 SL preparation of the highest concentration caused a significant increase of the sum. Similar results were reported by Gąstoł et al. (1999). Poniedziałek and Porębski (1995) discovered a significant impact of the $\mathrm{BA}+\mathrm{GA}_{3}$ mixture spray on the sum of the lateral shoot length, while the BA compound only slightly increased the sum of laterals because the shoots induced by it appeared to be too short. The previous studies by these authors (Poniedziałek and Porębski 1992) indicated that BA $+\mathrm{GA}_{4+7}$ and $\mathrm{BA}$ $+\mathrm{GA}_{3}$ mixtures affected the mean sum of shoot length, but no significant differences between the preparations applied were reported.

\section{CONCLUSIONS}

1. The growth regulators had a beneficial effect on lateral shoot numbers of maiden apple 
trees of the 'Šampion' and 'Jonica' cultivars. The maidens of the cultivars under study in the control combination formed fewer lateral shoots than after the application of the growth regulators.

2. The total shoot length of the studied maiden trees was dependent on the cultivar. The 'Jonica' maidens of had a greater total length of lateral shoots compared to the 'Šampion' ones.

3. The mean length of laterals was significantly dependent on the cultivar. The young 'Jonica' trees had significantly longer shoots than the 'Šampion' ones.

4. It was found that the 'Jonica' maidens showed weaker apical dominance than the young ‘Šampion' trees.

\section{REFERENCES}

Basak A., KoŁodziejczak P., Buban T., 1993. Paturyl 10 WSC as a branching agent for apple trees in nurseries. Acta Hort. 329: 201-203.

Bielicki P., Basak A., CzynczyK A., 1994. Wpływ nowych preparatów stymulujących rozgałęzianie na jakość okulantów dwóch odmian jabłoni. XXXIII Ogólnop. Nauk. Konf. Sad., Skierniewice: 53-56.

Bielicki P., Czynczyk A., Nowakowski Sz., 2003. Influence of plant material quality on growth and yield of apple cultivar 'Jonagored' grafted on M.9 rootstock. Folia Hort. Supl. 2: 143-145.

Czarnecki B., 1989. Sposoby produkcji rozgałęzionych okulantów jabłoni. Prace ISiK, ser. C, 3-4/103-104: 54-55.

Gąstol M., Poniedzialek W., Banach P., 1999. Wpływ preparatu Arbolin $036 \mathrm{SL}$ na rozgałęzianie się okulantów jabłoni. Zesz. Nauk. AR w Krakowie 351: 81-85

Hrotko K., Magyar L., Buban T., 1996. Improved feathering by benzyladenine application on one years old 'Idared' apple trees in the nursery. J. Hort. Sci. 28(3-4): 49-53.

JACYNA T., 1996. Induction of lateral brunching in nursery pear and apple trees with plant growth regulators. Fruit Var. J. 50(3): 151-156.

Jaumień F., Dziuban R., 1998. Wpływ Arbolinu 036 SL i maści Arbolin PA na rozgałęzianie okulantów jabłoni w latach 1995 i 1997. XXXVII Ogólnop. Nauk. Konf. Sad., 25-27 sierpień, Skierniewice: 25-30.

KAPŁAN M., 2006. The effect of preparations Arbolin 036 SL and Promalin 3.6 SL on growth maiden apple trees of 'Szampion' and 'Jonica' cultivars. Zesz. Nauk. ISiK Skierniewice 14: 37-44.

KapŁan M., BaryŁa P., 2006 a. The effect of growth regulators on the quality of two-year-old apple trees of 'Szampion' and 'Jonica' cultivars. Acta Sci. Pol., Hort. Cult. 5(1): 79-89.

KapŁan M., Baryea P., 2006 b. The effect of M.9 and M.26 rootstocks on the growth of maiden trees of 'Szampion' and 'Jonica' apple cultivars. Acta Agrobot. 59(2): 223-230.

Poniedzialek W., PoręBSKi S., 1992. Wpływ regulatorów wzrostu i uszczykiwania wierzchołków na tworzenie się bocznych pędów u okulantów odmiany 'Melrose'. Zesz. Nauk. AR w Krakowie 267: 21-34.

Poniedzialek W., PoręBski S., 1995. Wpływ sposobu traktowania okulantów jabłoni i gruszy w szkółce na ich rozgałęzianie się i wzrost. Zesz. Nauk. AR w Krakowie 302: 59-67.

Rejman A., Ścibisz K., Czarnecki B., 2002 Szkółkarstwo roślin sadowniczych. PWRiL, Warszawa.

Tromp J., 1992. The effect of soil temperature on lateral shoot formation and flower bud formation in apple in the frost year budding. J. Hort. Sci. 67(6): 787-793.

Wertheim S., Estabrooks E., 1994. Effect of repeated sprays of 6-benzyl-adenine on the formation of sylleptic shoots in apple in the fruit-tree nursery. Sci. Hort. 60(1-2): 31-39.

\section{WPŁYW REGULATORÓW WZROSTU NA STOPIEŃ ROZGAŁĘZIANIA OKULANTÓW JABŁONI ODMIAN 'ŠAMPION' I 'JONICA'}

Streszczenie: W latach 2000-2003 w Gospodarstwie Doświadczalnym Felin Akademii Rolniczej w Lublinie, przeprowadzono badania mające na celu ocenę wpływu: $\mathrm{BA}+\mathrm{GA}_{3}$ 2,2\% (Arbolin $036 \mathrm{SL}$ ) oraz $\mathrm{BA}+\mathrm{GA}_{4+7} 2,2 \%$ i 3,75\% (Promalin $3,6 \mathrm{SL}$ ) w postaci pasty lanolinowej na zwiększenie liczby pędów bocznych okulantów jabłoni odmian 'Šampion' i 'Jonica'. Wykazano, że zastosowane regulatory wzrostu korzystnie wpłynęły na stopień rozgałęziania okulantów jabłoni badanych odmian. Przeprowadzone badania wykazały, że odmiana 'Jonica' charakteryzuje się słabszą dominacją wierzchołkową niż odmiana 'Šampion'. Drzewka odmiany 'Jonica' charakteryzowały się większą liczbą i sumą długości pędów bocznych oraz dłuższymi pędami niż okulanty odmiany ‘Šampion’.

Received January 13, 2009; accepted November 25, 2010 